\title{
Mechanistic and evolutionary insights from comparative enzymology of phosphomonoesterases and phosphodiesterases across the alkaline phosphatase superfamily
}

\author{
Fanny Sunden ${ }^{1}$ \\ Ishraq AISadhan ${ }^{1}$ \\ Artem Y. Lyubimov $2,3,4,5,6$ \\ Susanne Ressl ${ }^{7}$ \\ Helen Wiersma-Koch ${ }^{1,8}$ \\ Jamar Borland ${ }^{1}$ \\ Clayton L. Brown Jr. ${ }^{1}$ \\ Tory A. Johnson ${ }^{1}$ \\ Zorawar Singh ${ }^{1}$ \\ Daniel Herschlag $1,9,10$,
}

\footnotetext{
${ }^{1}$ Department of Biochemistry, Beckman Center, Stanford University, Stanford, California 94305, USA; ${ }^{2}$ Departments of Molecular and Cellular Physiology; ${ }^{3}$ Neurology and Neurological Science; ${ }^{4}$ Structural Biology; ${ }^{5}$ Photon Science; ${ }^{6}$ Howard Hughes Medical Institute, Stanford University, Stanford, CA 94305, USA; Molecular and Cellular Biochemistry Department, Indiana University Bloomington, Bloomington, IN 47405, USA; ${ }^{8}$ Department of Biology, Indian River State College, Fort Pierce, FL 34981, USA; ${ }^{9}$ Departments of Chemical Engineering and Chemistry, Stanford University, Stanford, California 94305, USA; ${ }^{10}$ Stanford ChEM-H (Chemistry, Engineering, and Medicine for Human Health), Stanford University, Stanford, California 94305, USA
}

*Corresponding author: herschla@stanford.edu 
S1. PafA sequence. (A) The pafA gene has a periplasmic transportation signal (blue) and a terminator region (pink). (B) The sequence used to clone the pafA gene into the $\mathrm{pET} 22 \mathrm{~b}$ vector, using restriction enzymes BamH1 and EcoR1, after adding a Factor $X_{a}$ cleavage site and a strep tag (-WSHPQFEK). (C) The PafA protein product.

\title{
A PafA gene
}

\begin{abstract}
Unknown product, periplasmic export signal, terminator region
1 catatgccta ttgaaaagca gttattaatg ttattggtac taatgcttac cagtaaaggt 61 gttgcgggtg taccaagagc atcactaatt gttgtggttg ctacatgttc tatgtttggt 121 attccaccag aaggtattgc cttaattctg ccaatcgacc acttctgtga tatggcacgt 181 agtatgacca atgtattggg taatgctttg gctacaacag ctgtagataa atgggaaggg 241 catattgcag tagagcagga aagtatacat taataaata aaataatca tgttaacacc 301 gaagaagtgg ttactgggag ttcttgtagt atcaggaatg ctgggagccc aaaaacgaa 361 tgctgtacca agacctaaac ttgtggtagg actggtagtt gatcagatga gatgggatta 421 tctttaccgt tattatagca agtatggtga aggaggtttt aagagaatgc tgaataccgg 481 gtattcgtta aataatgttc atatagacta tgtacctaca gtaactgcaa tcggacatac 541 ttcaatttt acaggttctg ttccctccat ccacggaatt gcaggaaacg attggtatga 601 taaagaatta gggaaaagtg tttactgtac atctgatgaa acagtacaac cggtaggaac 661 tacttctaac tcggttggac aacattcacc aagaaacctt tggtctacta cggtaacaga 721 tcagctaggt ttggcaacaa actttacttc taaggttgtg ggggtctctc tgaaagacag 781 agcatcaatt ctgcctgcag ggcacaaccc aacaggagca ttttggttcg atgatactac 841 aggtaaattc attaccagta catattatac taagaatta cctaaatggg taaacgactt 901 taataataaa aatgttccgg ctcagttggt agctaatggc tggaatacac tattgcccat 961 taatcagtat acagaagct cagaagataa tgtggaatgg gaaggtttat tagggagtaa 1021 aaaacacct acattccctt atacagatct ggctaaagat tatgaagcta aaaaggatt 1081 aatccgtact acaccatttg gaaatacctt aactcttcag atggcagatg ctgcaattga 1141 tggtaaccaa atgggagttg atgatattac tgacttcctt acagtaaacc ttgcttcaac 1201 ggattatgtt ggacacaact ttggtccaaa ctctatagaa gttgaggata cttatctgag 1261 attagacaga gatttggctg acttcttcaa taaccttgat aaaaagttg gaaaagaaa 1321 ctaccttgta ttccttctg cggatcatgg cgctgcacat tctgtgggct ttatgcaagc 1381 acataaaatg ccaacaggct tctttgtaga agatatgaaa aaagaaatga acgctaagct 1441 gaagcaaaa ttcggtgctg ataatataat tgcagctgcg atgaactatc aggtttattt 1501 cgacagaaag gttttagcag acagcaaatt agaattggat gacgtaagag attatgtaat 1561 gacagaactt aaaaagagc catcagttct ttatgttctt agcacggatg aaatctggga 1621 atcgtctatt ccggaaccga taaagtccag agtaatcaat ggttataact ggaaagaag 1681 cggagatatt cagatcattt ctaaagacgg atatctttca gcatattcca aaaagggac 1741 aacacacagt gtatggaact cttatgattc acatattcct ttactcttta tggggtgggg 1801 tatcaaacag ggagagtcca atcagccata ccatatgacg gatattgcac caactgtttc 1861 atcattactt aaattcagt tccctagtgg tgctgtaggt aaaccaatta ccgaagttat 1921 aggaagataa acgaccaaaa atattactaa aatcctgata agatatttct tgtcaggatt 1981 tt
\end{abstract}




\section{B Cloned gene}

PafA + BamH1 + EcoR1 + Factor Xa + Strep

GAGGATCCGC aaaaaacgaa

361 tgctgtacca agacctaaac ttgtggtagg actggtagtt gatcagatga gatgggatta

421 tctttaccgt tattatagca agtatggtga aggaggtttt aagagaatgc tgaataccgg

481 gtattcgtta aataatgttc atatagacta tgtacctaca gtaactgcaa tcggacatac

541 ttcaattttt acaggttctg ttccctccat ccacggaatt gcaggaaacg attggtatga

601 taaagaatta gggaaaagtg tttactgtac atctgatgaa acagtacaac cggtaggaac

661 tacttctaac tcggttggac aacattcacc aagaaacctt tggtctacta cggtaacaga

721 tcagctaggt ttggcaacaa actttacttc taaggttgtg ggggtctctc tgaaagacag

781 agcatcaatt ctgcctgcag ggcacaaccc aacaggagca ttttggttcg atgatactac

841 aggtaaattc attaccagta catattatac taaagaatta cctaaatggg taaacgactt

901 taataataaa aatgttccgg ctcagttggt agctaatggc tggaatacac tattgcccat

961 taatcagtat acagaaagct cagaagataa tgtggaatgg gaaggtttat tagggagtaa

1021 aaaacacct acattccctt atacagatct ggctaaagat tatgaagcta aaaaggatt

1081 aatccgtact acaccatttg gaatacctt aactcttcag atggcagatg ctgcaattga

1141 tggtaaccaa atgggagttg atgatattac tgacttcctt acagtaaacc ttgcttcaac

1201 ggattatgtt ggacacaact ttggtccaaa ctctatagaa gttgaggata cttatctgag

1261 attagacaga gatttggctg acttcttcaa taaccttgat aaaaagttg gaaaaggaaa

1321 ctaccttgta ttcctttctg cggatcatgg cgctgcacat tctgtgggct ttatgcaagc

1381 acataaaatg ccaacaggct tctttgtaga agatatgaaa aaagaaatga acgctaagct

1441 gaagcaaaaa ttcggtgctg ataatataat tgcagctgcg atgaactatc aggtttattt

1501 cgacagaaag gttttagcag acagcaaatt agaattggat gacgtaagag attatgtaat

1561 gacagaactt aaaaagagc catcagttct ttatgttctt agcacggatg aaatctggga

1621 atcgtctatt ccggaaccga taaagtccag agtaatcaat ggttataact ggaaaagaag

1681 cggagatatt cagatcattt ctaaagacgg atatctttca gcatattcca aaaagggac

1741 aacacacagt gtatggaact cttatgattc acatattcct ttactcttta tggggtgggg

1801 tatcaaacag ggagagtcca atcagccata ccatatgacg gatattgcac caactgtttc

1861 atcattactt aaattcagt tccctagtgg tgctgtaggt aaaccaatta ccgaagttat

1921 aggaagaATC GAAGGTCGTTCCGCTTGTCCCACCCGCAGTTCGAAAAAtaa GAATTCAG

\section{Translated PafA product}

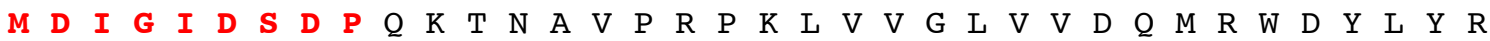

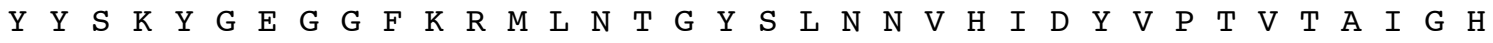

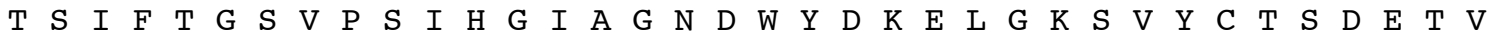
Q $\quad$ P $V$ V

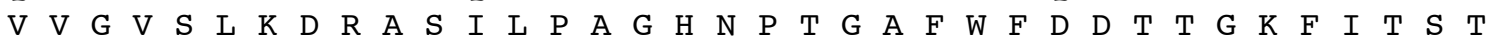

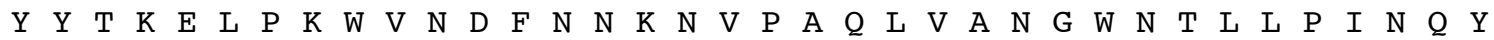

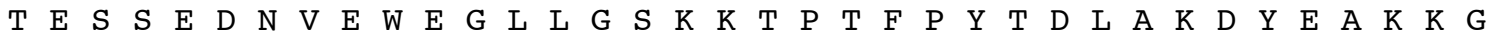

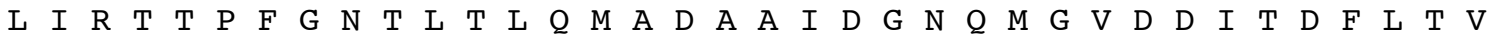

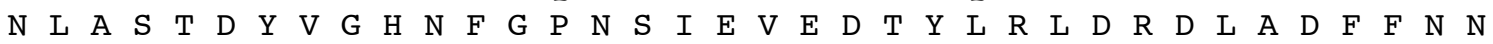

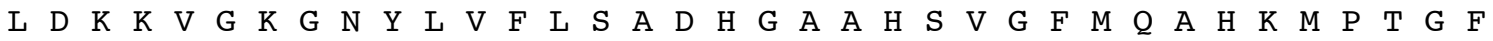

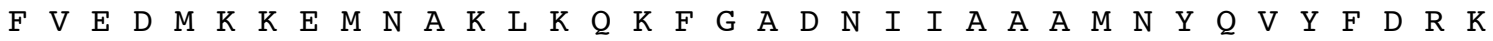
$\begin{array}{llllllllllllllllllllllllllllllllllll}V & L & A & D & S & K & L & E & L & D & D & V & R & D & Y & V & M & T & E & L & K & K & E & P & S & V & L & Y & V & L & S & T & D & E & I & W\end{array}$

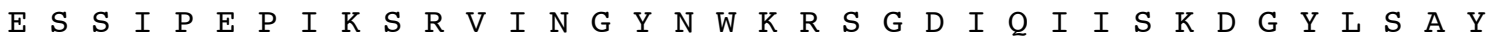

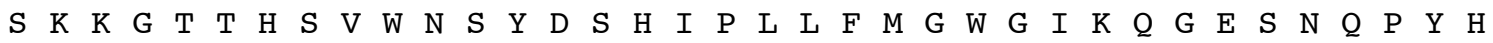

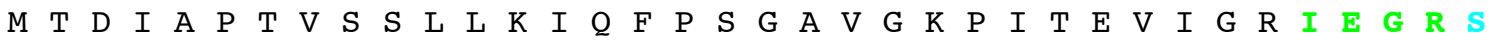
A W S H P Q F E K 
S2. $\mathrm{pH}$ dependencies for WT and mutant PafA variants for reactions of pNPP (circles) and me-pNPP (triangles). WT PafA, grey; T79S, black; N100A, blue; K162A, green; and R164A, purple.

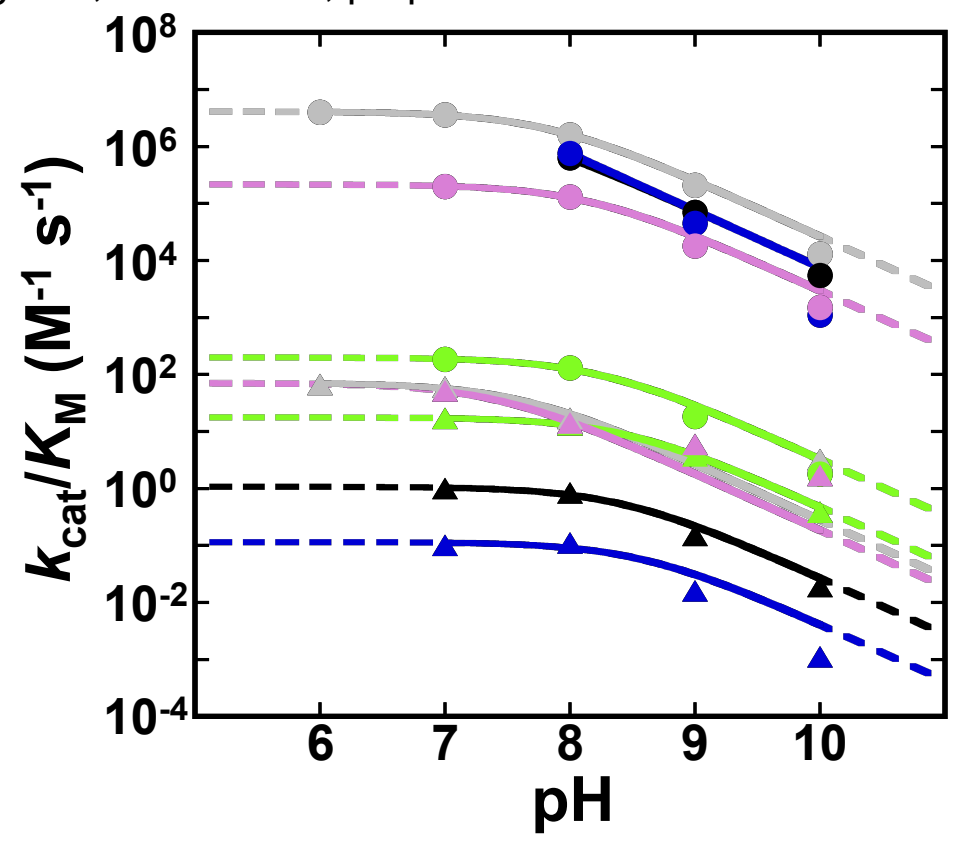




\section{S3. Inhibition of cognate and promiscuous activity for WT mutant and PafA}

variants. (A-D) Comparisons of the inhibition by vanadate of the monoesterase (pNPP, black) and diesterase (me-pNPP, grey) reactions for (A) WT PafA, (B) T79S, (C) K162A, and (D) R164A at pH 8.0. (E) Comparison of the inhibition by tungstate of the monoesterase (pNPP, black) and diesterase (me-pNPP, grey) reaction of $\mathrm{N} 100 \mathrm{~A}$ at $\mathrm{pH} 9.0$. Activity of each reaction was normalized to the observed reaction with no inhibitor, and the data were fit to a nonlinear least square fit for competitive inhibition with a fixed end point of zero. 

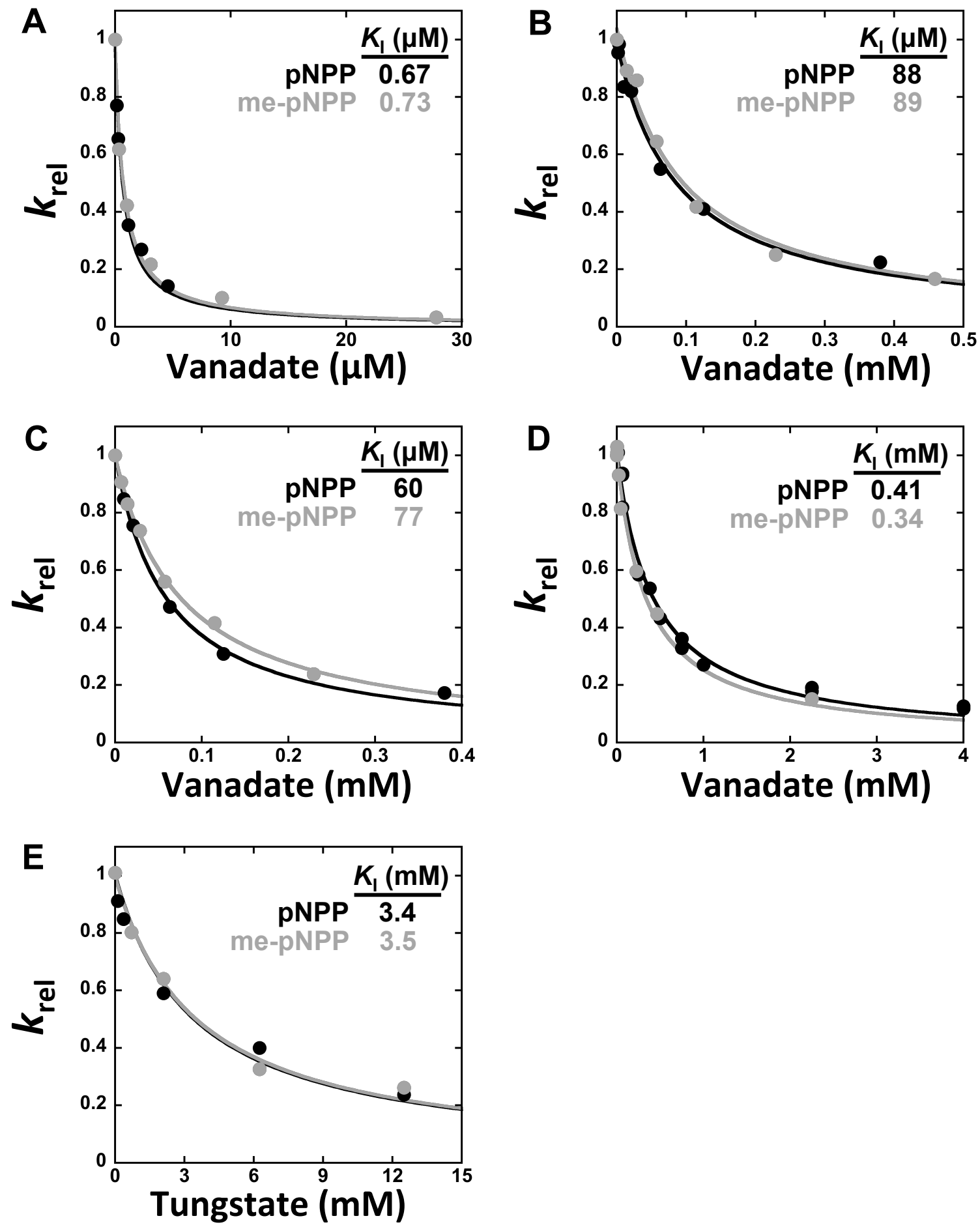


\section{S4. Determining the rate of Me-P for K162A and the rate of Me-P for T79S}

and N100A at pH 8. To estimate the $k_{\text {cat }} / K_{\mathrm{M}}$ value for the K162A PafA (the slowest variant) we noticed that the ratio of $k_{\mathrm{cat}} / K_{\mathrm{M}}$ values for Ph-P:Me-P (and pNPP:Me-P) were similar for the two slowest reacting PafA variants that could be measured and smaller for the other variants (Supporting Information S4, Fig. 1). This observation supports the assumption of a constant relative reactivity for different substrates when the chemical step is rate limiting. We therefore assumed that this same ratio holds for K162A PafA, for which only a $k_{\text {cat }} / K_{M}$ limit could be obtained with Me-P. Using the average ratio of 460 gives an estimated $\left(k_{\text {cat }} / K_{M}\right)_{\text {Me-P }}$ for K162A PafA of $0.02 \mathrm{M}^{-1} \mathrm{~s}^{-1}$ (eq S1), and this value is used in the main text. A similar value is obtained if the pNPP:Me-P ratios are used instead (not shown). The use of the measured limit would not alter any of the conclusions drawn in this work, as noted in the main text.

For T79S and N100A Me-P and Ph-P $k_{\text {cat }} / K_{\mathrm{M}}$ were measured at $\mathrm{pH} 9.0$ rather than $\mathrm{pH} 8.0$, as the low $K_{\mathrm{M}}$ values at $\mathrm{pH} 8.0$ prevented measurement of accurate $k_{\text {cat }} / K_{\mathrm{M}}$ values. The $k_{\mathrm{cat}} / K_{\mathrm{M}}$ at pH 8.0 were estimated using the ratio of $k_{\text {cat }} / K_{\mathrm{M}}$ for pNPP at pH 8.0 and pH 9.0 (Table S4), as described in the Experimental Section (see "Kinetic Assays of PafA Variants").

$$
\left(\frac{k_{c a t}}{K_{\mathrm{M}}}\right)_{\mathrm{Me}-\mathrm{P}}^{\mathrm{K} 162}=\left(\frac{k_{c a t}}{K_{\mathrm{M}}}\right)_{\mathrm{Ph}-\mathrm{P}} \times \frac{1}{\mathrm{R}_{\mathrm{Ph}-\mathrm{P} / \mathrm{Me}-\mathrm{P}}^{*}}
$$




$$
\mathrm{R}_{\mathrm{Ph}-\mathrm{P} / \mathrm{Me}-\mathrm{P}}^{*}=\left\{\frac{\left(\frac{k_{\mathrm{cat}}}{K_{\mathrm{M}}}\right)_{\mathrm{Ph}-\mathrm{P}}}{\left(\frac{k_{\mathrm{cat}}}{K_{\mathrm{M}}}\right)_{\text {Me-P }}}\right\}_{\text {Average }}
$$


S4: Fig 1. Ratio of $k_{\mathrm{cat}} / K_{\mathrm{M}}$ values for PafA variants. Ratios are from $\left(k_{\mathrm{cat}} / K_{\mathrm{M}}\right)$ values in Table 3.

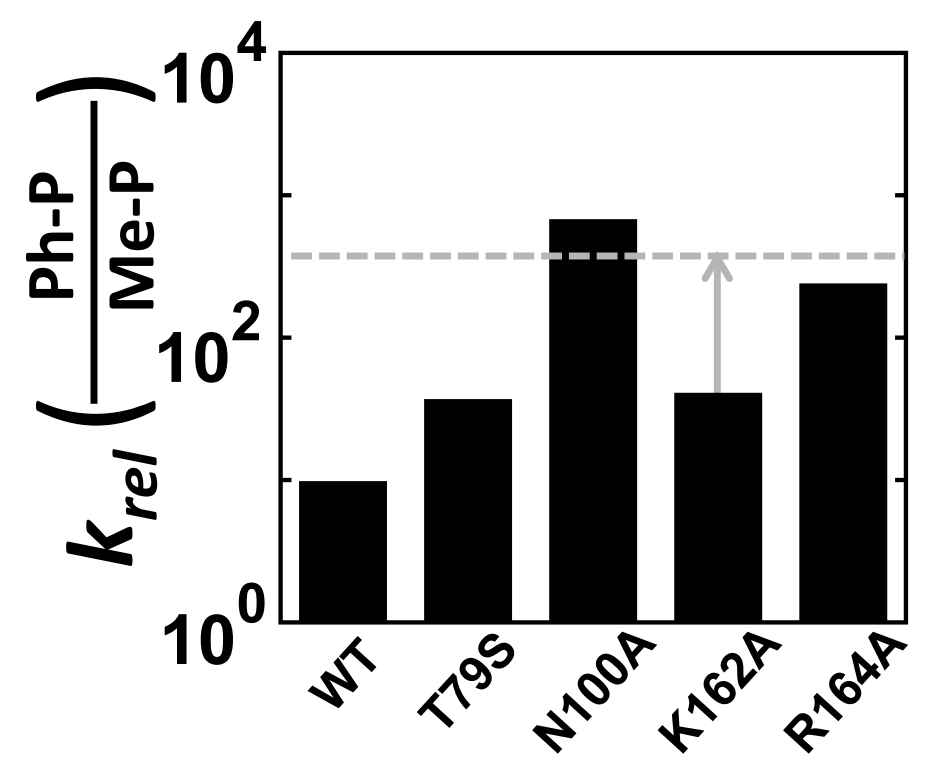

S4: Table 1. pNPP and me-P rates at $\mathrm{pH} 8$ and $9^{\mathrm{a}}$

\begin{tabular}{lcccc}
\hline Enzyme & pH & $\begin{array}{c}\text { pNPP } \\
\left(\mathbf{M}^{-1} \mathbf{s}^{-1}\right)\end{array}$ & $\begin{array}{c}\mathbf{P h}-\mathbf{P} \\
\left(\mathbf{M}^{-1} \mathbf{s}^{-1}\right)\end{array}$ & $\begin{array}{c}\text { Me-P } \\
\left(\mathbf{M}^{-1} \mathbf{s}^{-1}\right)\end{array}$ \\
\hline & 8 & $6.3(1.5) \times 10^{5}$ & $1.4 \times 10^{5 b}$ & $3.8 \times 10^{3 \mathrm{~b}}$ \\
T79S & 9 & $7.0(1.8) \times 10^{4}$ & $1.5(0.3) \times 10^{4}$ & $4.2(2.4) \times 10^{2}$ \\
N100A & 8 & $7.6(2.0) \times 10^{5}$ & $1.5 \times 10^{5 b}$ & $2.20 \times 10^{2 b}$ \\
& 9 & $4.5(1.6) \times 10^{4}$ & $8.6(2.8) \times 10^{3}$ & $1.3(0.3) \times 10^{1}$ \\
\hline
\end{tabular}

a Assay conditions, $100 \mathrm{mM}$ sodium MOPS, pH 8.0, $500 \mathrm{mM} \mathrm{NaCl}, 100 \mu \mathrm{M}$ $\mathrm{ZnCl}_{2}$, unless annotated (pH 9.0) for which $100 \mathrm{mM}$ sodium $\mathrm{CHES}, \mathrm{pH} 9.0,500$ $\mathrm{mM} \mathrm{NaCl}, 100 \mu \mathrm{M} \mathrm{ZnCl} 2$ was used.

${ }^{\mathrm{b}} k_{\mathrm{cat}} / K_{\mathrm{M}}$ was measured at $\mathrm{pH} 9.0$ rather than $\mathrm{pH} 8.0$ for these substrates and mutants, as the low $K_{\mathrm{M}}$ values at $\mathrm{pH} 8.0$ prevented measurement of accurate $k_{\text {cat }} / K_{\mathrm{M}}$ values. The $k_{\text {cat }} / K_{\mathrm{M}}$ at $\mathrm{pH} 8.0$ were estimated using the ratio of $k_{\text {cat }} / K_{\mathrm{M}}$ for pNPP at pH 8.0 and pH 9.0, as described in the Experimental Section (see "Kinetic Assays of PafA Variants"). 
S5: Sequence analysis of PafA to SPAP, EcAP and NPP. Protein sequences obtained by translating the genes for PafA (UniProtKB/Swiss-Prot: AF157621.2), SPAP (UniProtKB/Swiss-Prot: A1YYW7.1), NPP (UniProtKB/Swiss-Prot: AAM37669.1) and EcAP, (UniProtKB/Swiss-Prot: AAG54729.1) were aligned with EMBOSS Stretcher using BLOSUM 62, with a GAP open penalty of 12 and extend penalty of 2 against PafA ( 55 , Table 1). The reported sequence similarity between the amino acid sequences is a function of the divergence time and substitution rates. The sequences were also aligned using a structure-sequence based approach using Chimera ${ }^{1}$ taking into account structural similarities of the enzymes. The following pdb codes were used to do the structural alignment to PafA: SPAP (3Q3Q), EcAP (1ALK), and NPP (2RH6), using the Smith-Waterman algoritm (local), BLOSUM-50 and a secondary structure score of $80 \%$. A multiple alignment was carried out with PafA as a reference and a cut-off residue-residue distance of $5 \AA$ with 3 cycles of iteration. The sequence identity was calculated based on the length of PafA (S5, Table 1). The RMSD was calculated based on the 181 populated columns in the final alignments (S5, Fig1). S5, Fig 2, is a structural overlay of the $\mathrm{Zn}^{2+}$ ions, their ligands, and the nucleophiles in the active sites of EcAP, PafA and NPP.

S5: Table 1. Sequence comparison PafA, to EcAP, SPAP and NPP

\begin{tabular}{lcccc}
\hline $\begin{array}{l}\text { Compared } \\
\text { Enzyme }\end{array}$ & $\begin{array}{c}\text { Sequence alignment } \\
\text { EMBOSS Stretcher } \\
\text { Identity } \\
(\%)\end{array}$ & $\begin{array}{c}\text { Similarity } \\
(\%)\end{array}$ & $\begin{array}{c}\text { Sequence/structure } \\
\text { alignment Chimera } \\
\text { Identity } \\
(\%)\end{array}$ & $\begin{array}{c}\text { RMSD } \\
(\mathbf{A})\end{array}$ \\
\hline ECAP & 16.7 & 31.3 & 8.9 & 2.2 \\
SPAP & 27.4 & 43.5 & 23.6 & 1.2 \\
NPP & 16.2 & 27.6 & 10 & 1.9 \\
\hline
\end{tabular}


S5: Fig 1. Structure based Alignment of PafA, SPAP, NPP, and EcAP. Sequence alignment of EcAP (blue), NPP (red), PafA (green) and SPAP (purple) based on Chimera structural alignment. The sequences are colored red for loop regions, yellow for helices, and green for sheets. The conserved helices and sheets shown in the topology diagrams of Fig. 1B are highlighted, as are the conserved zinc ligands and nucleophile (boxes, solid line), and additional residues that fully conserved among these proteins (boxes, dashed lines). The bar graphs above the sequence alignments $C$..on, reflects the conservation of the residue position. 


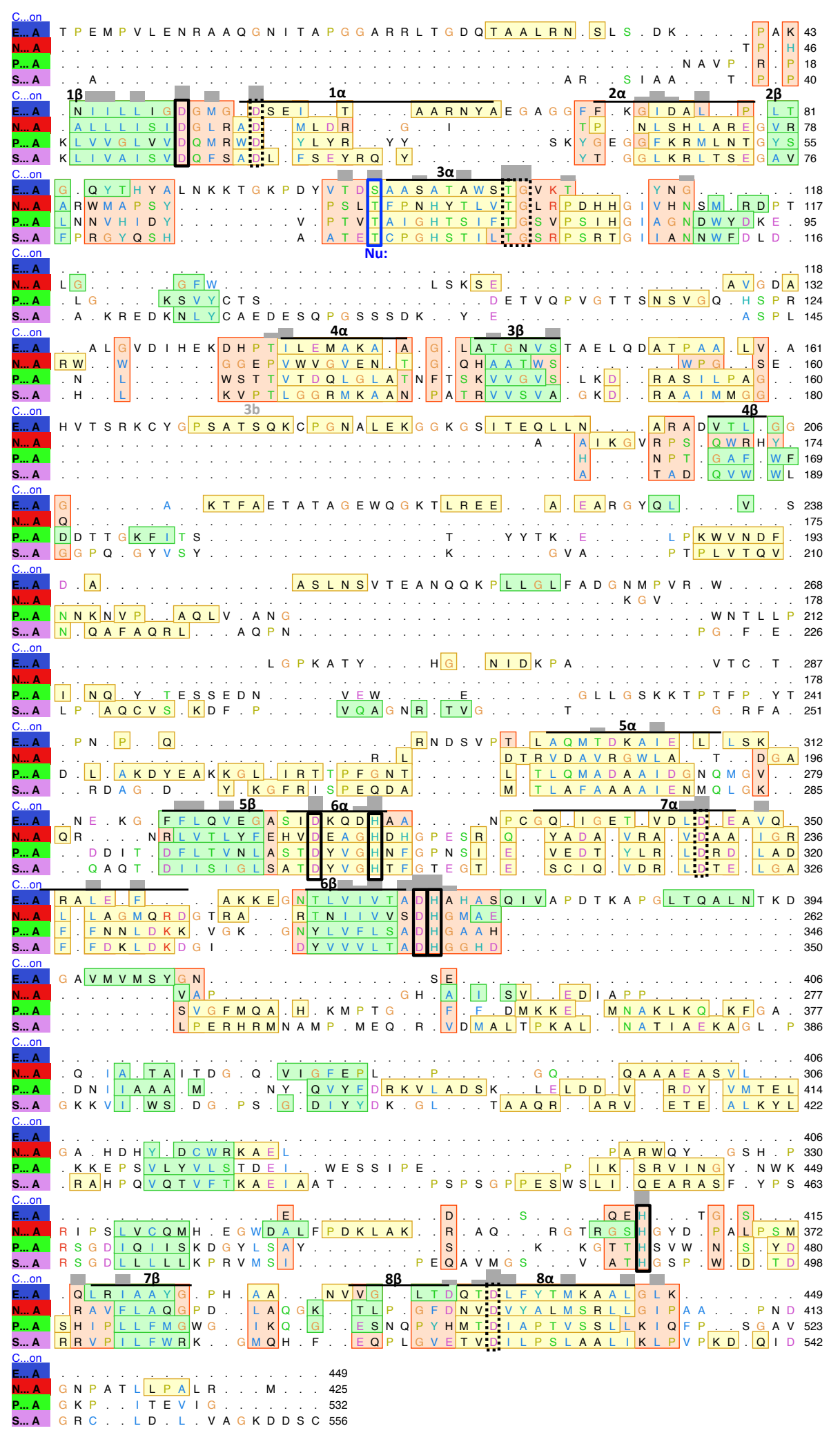


S5: Fig 2. Structural superimposition of PafA, NPP, and EcAP active sites.

Superimposition of zincs, zinc ligands and nucleophiles of PafA (green), NPP (magenta) and EcAP (blue) using Pymol. The ligands are numbered according to the PafA sequence.

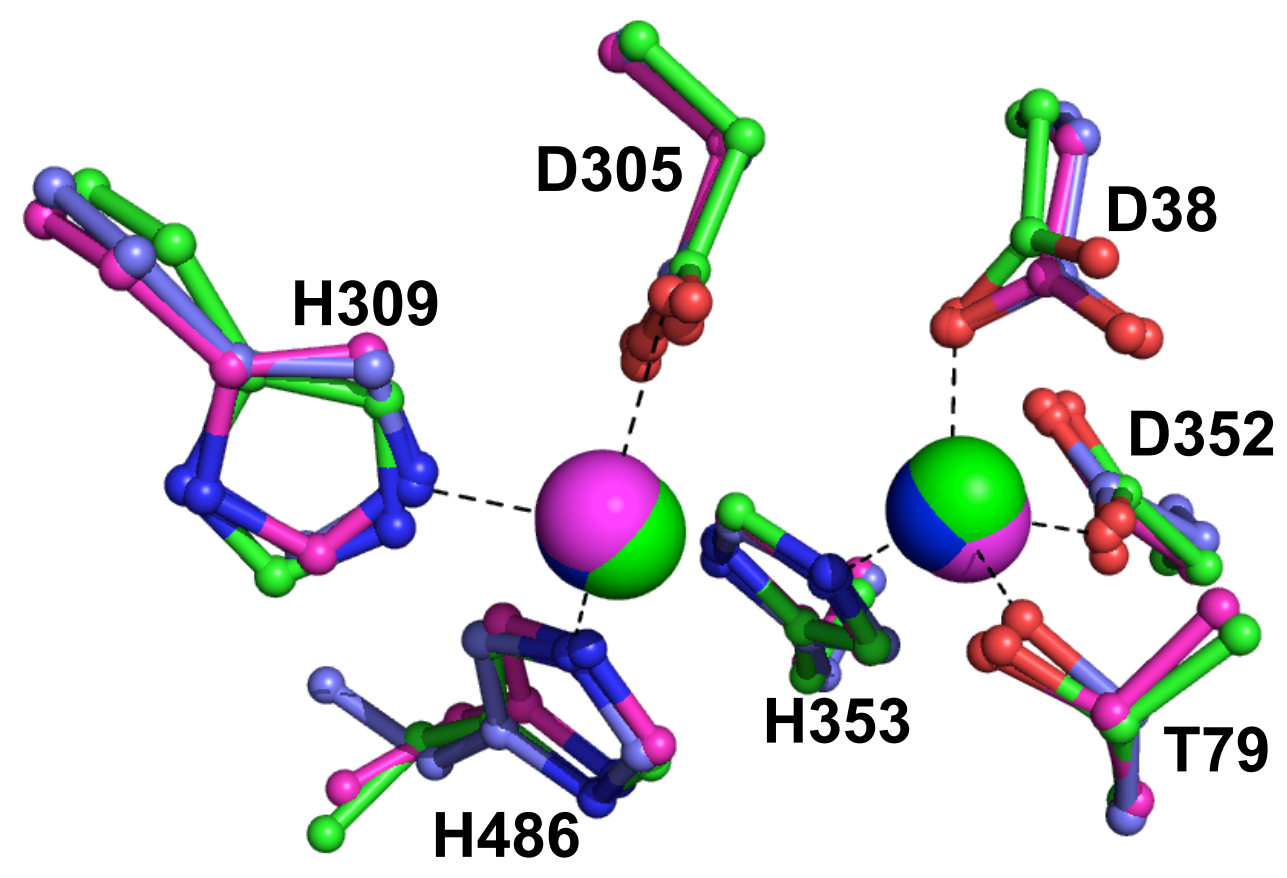


S6. Structural superimposition PafA and SPAP. SPAP and PafA are similar with respect to overall structure and active site, although there are some differences in the auxiliary domains and active site: some of the helices and sheets in the auxiliary domains are not conserved (see S6, Fig. 1), and some helices and several loops are re-orientated and of different lengths (structural overlay; S6, Fig. 2). The residues contacting the substrate are the same and have the same orientation (S6, Fig. 3 \& not shown). 
S6: Fig 1. Topology diagrams of PafA (orange) and SPAP (green). The overall fold of SPAP and PafA are similar. The SPAP auxiliary domains (orange) contain three additional pairs of $\beta$ sheets $(2 a / 2 b, 4 b / 4 c$, and $6 a / 6 f)$ than annotated in the PafA structure and have an additional auxiliary a helix (7d). PafA has three more $\alpha$ helices than SPAP (green, $4 d, 4 e$ and $7 c$ ).

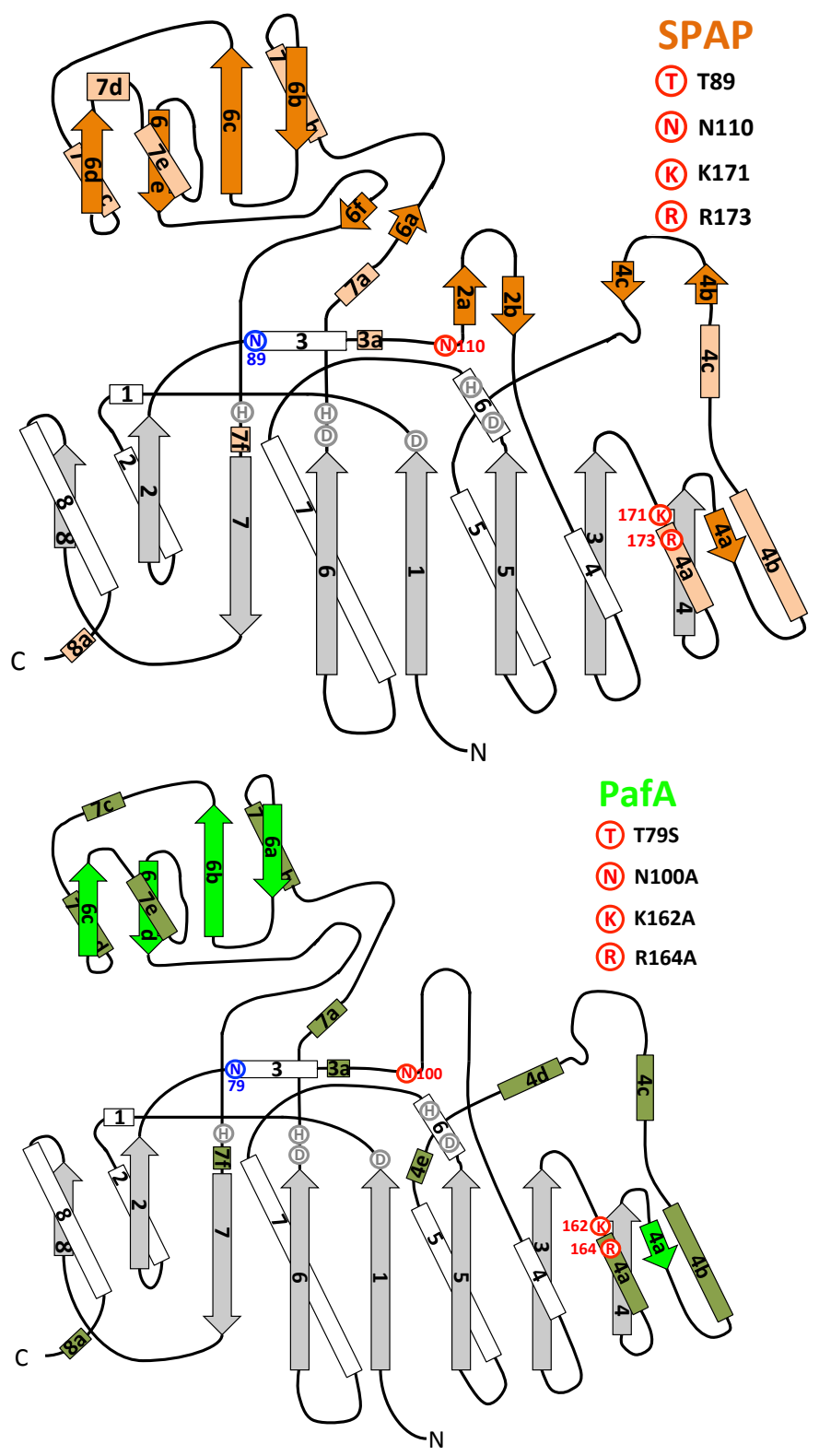


S6: Fig 2. Structural overlay of PafA (green) and SPAP (grey). The overall fold is similar between PafA and SPAP, with a RMSD of $1.18 \AA$ for 309 aligned atoms, but there are loops and helixes that are re-arranged and not conserved between the structures, resulting in an RMSD of $2.35 \AA$ between 482 residues.

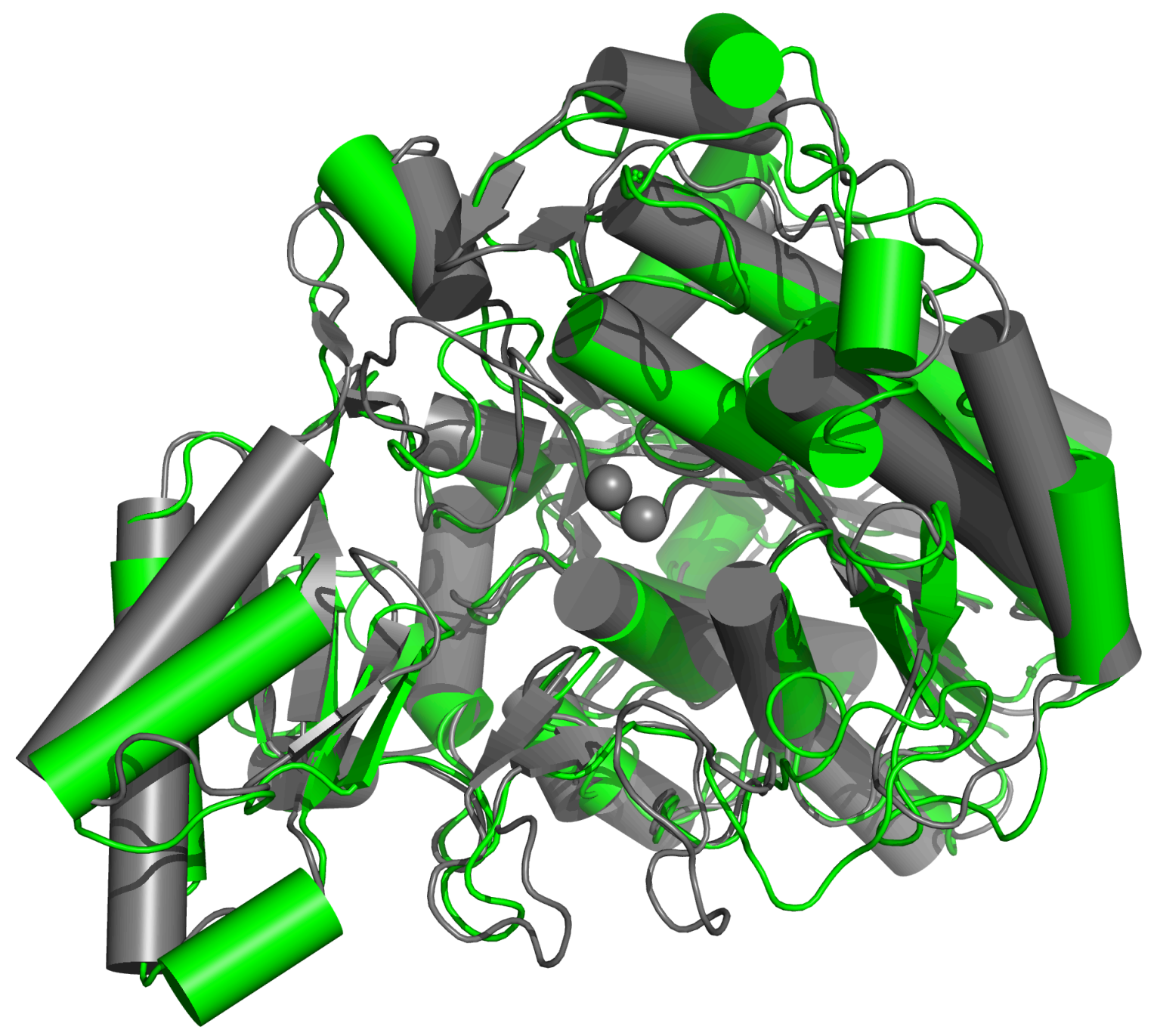




\section{S6: Fig 3. Active site of PafA and SPAP}

Schematic of active sites of PafA, in green, and SPAP in grey. The bimetallo zinc motif, nucleophilic threonine and active site Lys, Arg and Asn are conserved between SPAP and PafA.
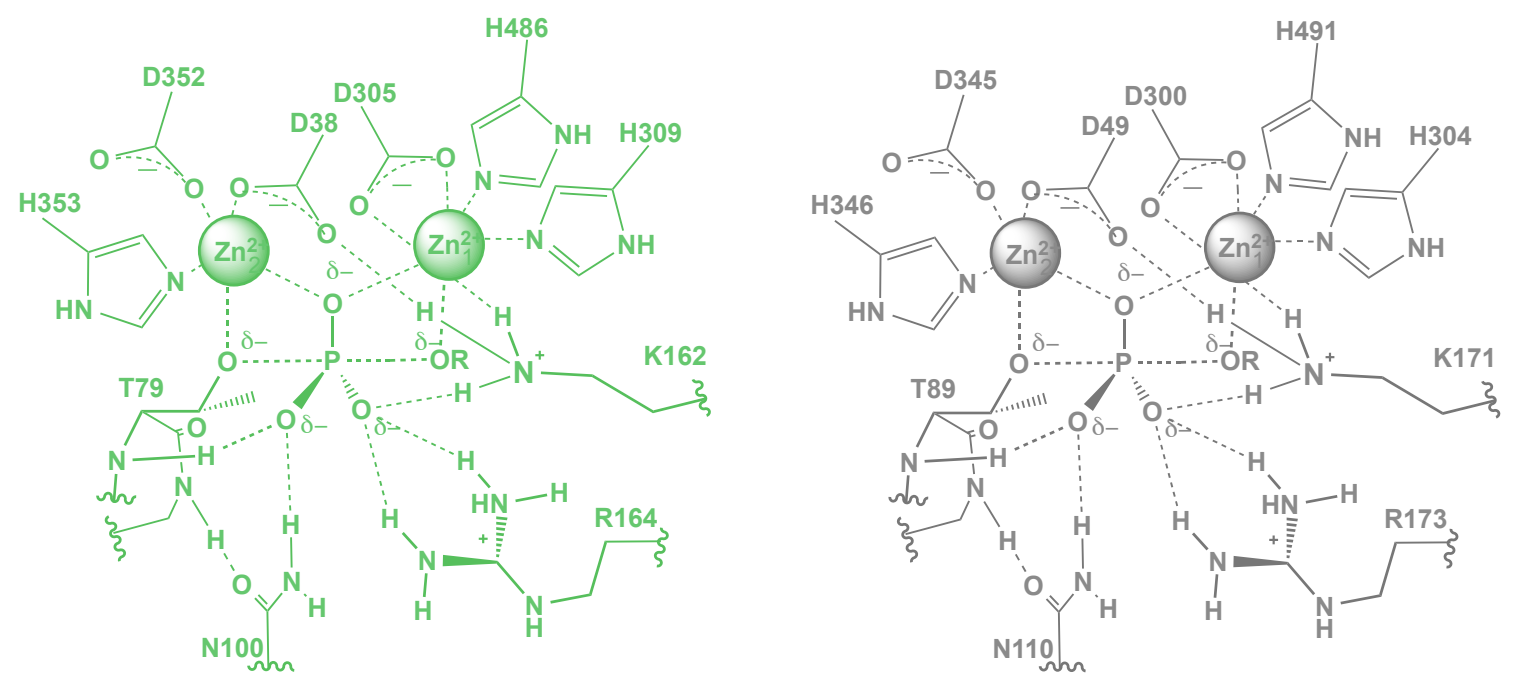
S7: Fig. 1. Packing of auxiliary domains from PafA (A) and NPP (B). (A) PafA: the dark green is the auxiliary domain inserted between conserved sheets 6 and 7 (Fig. 1B). It packs against the loop inserted between conserved helix 3 and 4 (light green). N100 sits at the beginning of the loop and may be positioned by the auxiliary domain in dark green. (B) NPP: the dark pink is the auxiliary domain inserted between conserved sheets 6 and 7 (Fig. 1B). It packs against the loop inserted between conserved helix 3 and 4 (light pink). The rest of the auxiliary domains are colored in green for PafA, and pink for NPP.

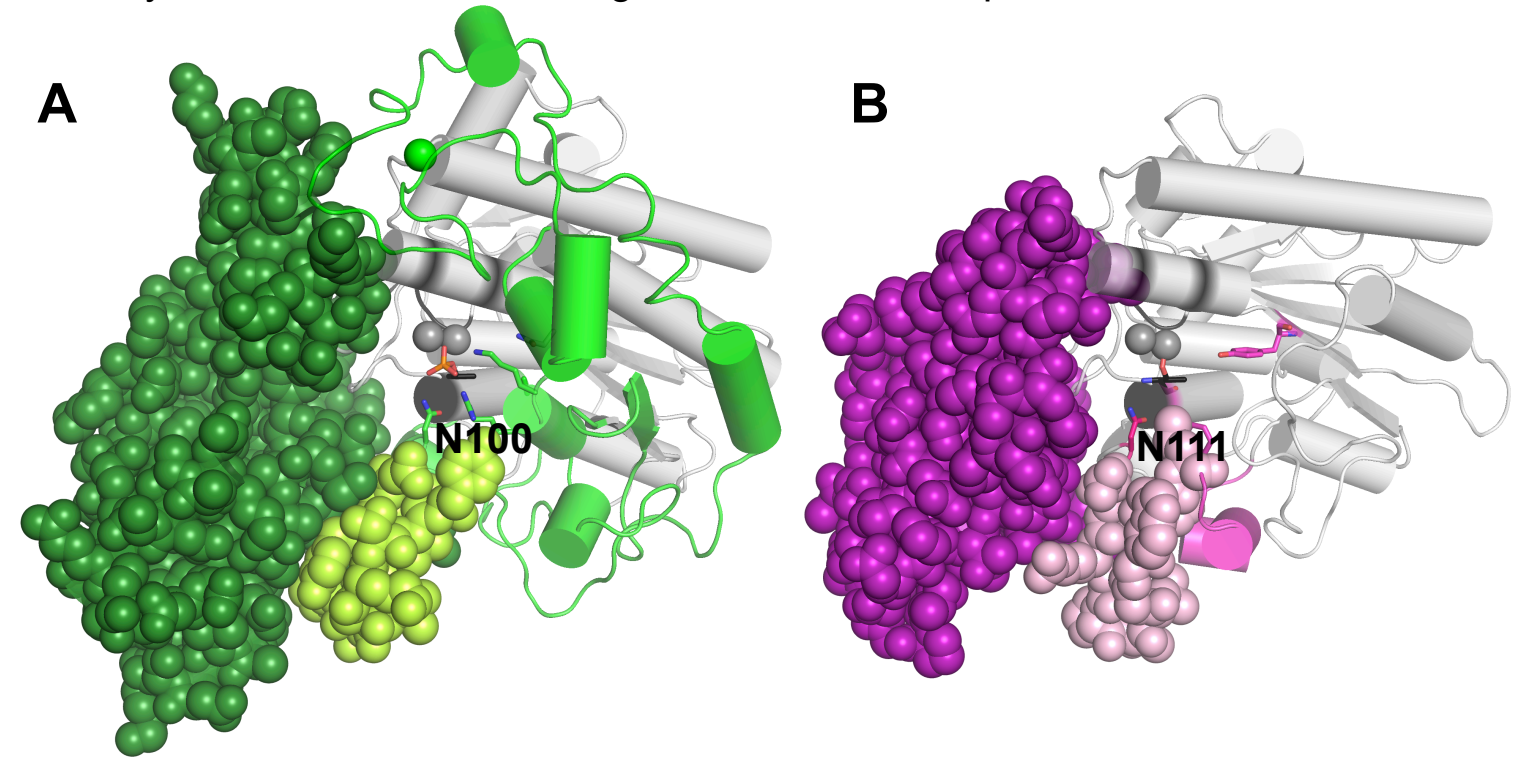




\section{S8: Table 1. Structurally Characterized Bimetallo Alkaline Phosphatase}

Superfamily Members: Analysis of Insertion Elements

\begin{tabular}{|c|c|c|c|c|c|c|}
\hline $\begin{array}{l}\text { Abbrevi } \\
\text { ation }\end{array}$ & Cognate Reaction & Organism & Helix $4 a^{a}$ & $\begin{array}{c}\mathrm{N} 100 \\
\text { Equivalent }^{\mathrm{a}, \mathrm{b}}\end{array}$ & $\begin{array}{c}\text { Insert } \\
\beta 6 / 7^{\mathrm{a}}\end{array}$ & $\begin{array}{l}\text { Pdb } \\
\text { code }\end{array}$ \\
\hline EcAP & Phophomonoesterase & Escherichia coli & D153-V160 & - & - & $3 \operatorname{tg} 0^{2}$ \\
\hline NPP & Phophodiesterase & Xanthomonas Citri & - & N111 & Yes & $2 \mathrm{gso}^{3}$ \\
\hline ENPP1 & Phosphodiesterase & Homo Sapiens & - & N259 & Yes & $4 \mathrm{~b} 56^{4}$ \\
\hline ENPP2 & $\begin{array}{l}\text { Lysophospholipase } \\
\text { (Phosphodiester) }\end{array}$ & Mus musculus & - & N230 & Yes & $3 n k r^{5}$ \\
\hline ENPP2 & $\begin{array}{l}\text { Lysophospholipase } \\
\text { (Phosphodiester) }\end{array}$ & Rattus norvegicus & - & N230 & Yes & $5 \mathrm{DLT}^{6}$ \\
\hline ENPP4 & Phosphodiesterase & Homo Sapiens & - & N91 & Yes & 4LR2' \\
\hline ENPP6 & $\begin{array}{l}\text { Choline-specific } \\
\text { glycerophosphodiester- } \\
\text { phosphodiesterase }\end{array}$ & Mus musculus & - & N92 & Yes & $5 \mathrm{EGH}^{8}$ \\
\hline IAP & Phosphomonoesterase & Rattus norvegicus & H153-T159 & - & - & $4 \mathrm{kjg}^{9}$ \\
\hline PafA & Phophomonoesterase & $\begin{array}{l}\text { Chryseobacterium } \\
\text { meningosepticum }\end{array}$ & D163-A170 & N100 & Yes & - \\
\hline SPAP & Phophomonoesterase & $\begin{array}{l}\text { Sphingomonas sp. } \\
\text { BSAR-1 }\end{array}$ & D153-A160 & N110 & Yes & $3 Q^{3} Q^{10}$ \\
\hline VLAP & Phophomonoesterase & Vibrio sp. G15-21 & H116-S121 & - & - & $3 \mathrm{E} 2 \mathrm{D}^{11}$ \\
\hline PLAP & Phophomonoesterase & Homo Sapiens & H153-Y160 & - & - & 1ZEB $^{12}$ \\
\hline SAP & Phophomonoesterase & $\begin{array}{l}\text { Pandalus borealis } \\
\text { (northern shrimp) }\end{array}$ & H149-T155 & - & - & ${ }_{3}^{1} \mathrm{SHQ}^{1}$ \\
\hline $\begin{array}{l}\text { PACH } \\
\text { SM }\end{array}$ & $\begin{array}{l}\text { Phosphonoacetate } \\
\text { hydrolase }\end{array}$ & Sinorhizobium meliloti & L130-G138 & N89 & Yes & $3 \mathrm{~T} 00^{14}$ \\
\hline $\begin{array}{l}\text { PACH } \\
\text { PF }\end{array}$ & $\begin{array}{l}\text { Phosphonoacetate } \\
\text { hydrolase }\end{array}$ & $\begin{array}{l}\text { Pseudomonas } \\
\text { fluorescens }\end{array}$ & K126-G134 & N85 & Yes & $1 e i 6^{15}$ \\
\hline PPM BC & Phosphopentomutase & Bacillus cereus & G239-Y245 & - & - & $3 m 8 z^{16}$ \\
\hline PPM SM & Phosphopentomutase & Streptococcus Mutans & K249-N254 & - & - & $3 m 7 v^{11}$ \\
\hline SCAP & Phophomonoesterase & Shewanella sp. AP1 & H109-T117 & - & - & $3 \mathrm{~A} 52^{18}$ \\
\hline HSAP & Phophomonoesterase & $\begin{array}{l}\text { Halobacterium } \\
\text { salinarum }\end{array}$ & H170-A178 & - & - & $2 \times 98^{19}$ \\
\hline HaAP & Phophomonoesterase & Halomonas sp. & H116-A121 & - & - & $3 w b h^{20}$ \\
\hline $\begin{array}{l}\text { Lm } \\
\text { iPGM }\end{array}$ & Phosphoglycerate mutase ${ }^{2}$ & Leishmania Mexicana & T355-W365 & - & - & $3 \mid \mathrm{GZ}^{21}$ \\
\hline iPGM & Phosphoglycerate mutase & Trypanosoma brucei & T354-T361 & - & - & $3 \mathrm{NVL}^{22}$ \\
\hline iPGM & Phosphoglycerate mutase & $\begin{array}{l}\text { Geobacillus } \\
\text { stearothermophilus }\end{array}$ & K336-T341 & - & - & $1098^{23}$ \\
\hline iPGM & Phosphoglycerate Mutase & Bacillus anthracis & K335-T340 & - & - & $2 \mathrm{IFY} \mathrm{Y}^{24}$ \\
\hline iPGM & Phosphoglycerate Mutase & Staphylococcus Aureus & E329-T335 & - & - & $4 m y 4^{25}$ \\
\hline iPGM & $\begin{array}{l}\text { Phosphoglycerate mutase } \\
\text { (putative; uncharacterized) }\end{array}$ & Pyrococcus Horikoshii & V252-V262 & - & - & $2 z k t^{26}$ \\
\hline TAP & phophomonoesterase & $\begin{array}{l}\text { Antarctic bacterium } \\
\text { TAB5 }\end{array}$ & H135-F141 & - & - & $2 I U C^{2 I}$ \\
\hline
\end{tabular}

a '-,' indicates that the noted residue or element is absent in the structure.

b 'N100 equivalent,' refers to an asparagine in the active site of an Alkaine

Phosphatase superfamily member positioned between conserved helices 3 and

4 , positioned in the structure opposite of the nucleophile. 


\section{S9. Specificity Helix in Alkaline Phosphatase Superfamily Phosphate}

\section{Monoesterases.}

After conserved sheet 3 in PafA and EcAP there is an additional helix (4a) that is lacking in NPP (Fig. 1B; S9 Fig. 1). This insert is found in all structurally

characterized AP superfamily members catalyzing reactions of mono-substituted phosphates but is absent in all those catalyzing reactions of phosphate diesters (see S8: Table 1).

S9: Fig. 1. Helix 4a of PafA and EcAP. Auxiliary domains are shown in color for PafA (green), EcAP (blue), and NPP (magenta). PafA and EcAP contain helix 4a that is absent in NPP. This helix may be important for positioning the residues for phosphate monoester specificity, including K162 and R164 in PafA, and D153 and the $\mathrm{Mg}^{2+}$ ion in EcAP. Conversely, this element may prevent larger diester groups, such as AMP as shown in the NPP active site, from binding and thus may need to be removed to optimize phosphate diesterase activity.

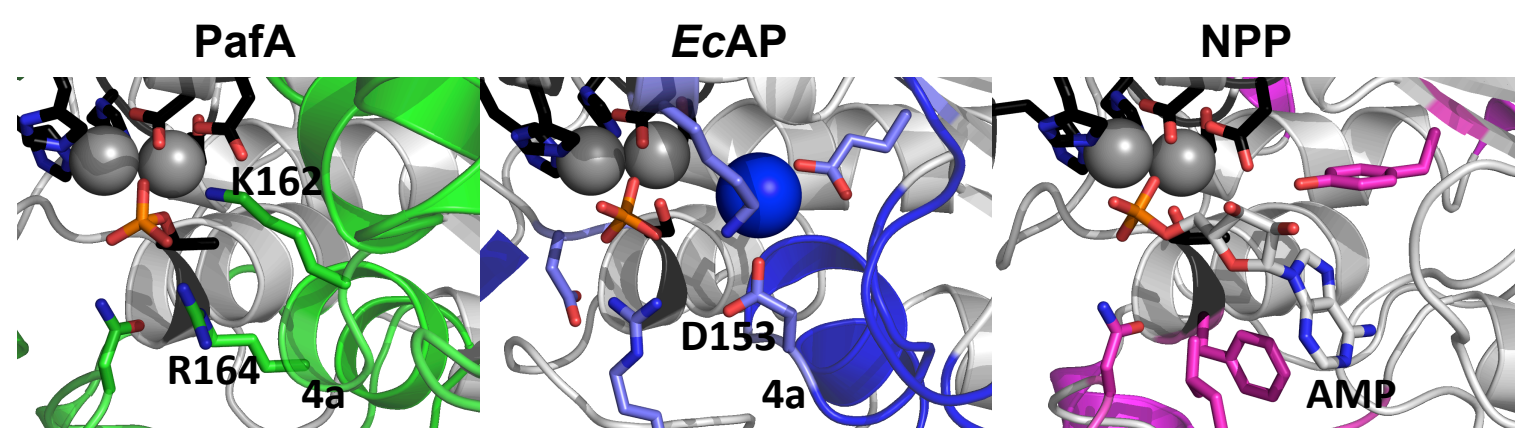




\section{References for Supporting Information}

(1) Pettersen, E. F., Goddard, T.D., Huang, C.C., Couch, G.S., Greenblatt, D.M., Meng, E.C., Ferrin, T.E. J. Comput. Chem. 2004, 25, 1605.

(2) Bobyr, E., Lassila, J. K., Wiersma-Koch, H. I., Fenn, T. D., Lee, J. J., Nikolic-Hughes, I., Hodgson, K. O., Rees, D.C., Hedman, B., Herschlag, D. J. Mol. Biol. 2012, 415, 102.

(3) Zalatan, J. G., Fenn, T. D., Brunger, A. T., Herschlag, D. Biochemistry 2006, 45, 9788.

(4) Jansen, S., Perrakis, A., Ulens, C., Winkler, C., Andries, M., Joosten, R.P., Van Acker, M., Luyten, F.P., Moolenaar, W.H., Bollen, M. Structure 2012, 20, 1948.

(5) Nishimasu, H., Okudaira, S., Hama, K., Mihara, E., Dohmae, N., Inoue, A., Ishitani, R., Takagi, J., Aoki, J., Nureki, O. Nat. Struct. Biol. 2011, 18, 205.

(6) Keune, W. J., Hausmann, J., Bolier, R., Tolenaars, D., Kremer, A., Heidebrecht, T., Joosten, R.P., Sunkara, M., Morris, A.J., Matas-Rico, E., Moolenaar, W.H., Oude Elferink, R.P., Perrakis, A. Nat. Commun. 2016, 7, 11248.

(7) Albright, R. A., Ornstein, D.L., Cao, W., Chang, W.C., Robert, D., Tehan, M., Hoyer, D., Liu, L., Stabach, P., Yang, G., De La Cruz, E.M., Braddock, D.T. J. Biol.

Chem. 2014, 289, 3294.

(8) Morita, J., Kano, K., Kato, K., Takita, H., Sakagami, H., Yamamoto, Y., Mihara, E., Ueda, H., Sato, T., Tokuyama, H., Arai, H., Asou, H., Takagi, J., Ishitani, R., Nishimasu, H., Nureki, O., Aoki, J. Sci. Rep. 2016, 6, 20995.

(9) Ghosh, K., Mazumder Tagore, D., Anumula, R., Lakshmaiah, B., Kumar, P.P., Singaram, S., Matan, T., Kallipatti, S., Selvam, S., Krishnamurthy, P., Ramarao, M. J. Struct. Biol. 2013, 184, 182.

(10) Bihani, S. C., Das, A., Nilgiriwala, K. S., Prashar, V., Pirocchi, M., Apte, S. K., Ferrer, J., Hosur, M. V. PloS one 2011, 6, 1.

(11) Helland, R., Larsen, R. L., Asgeirsson, B. Biochim. Biophys. Acta. 2009, 1794, 297.

(12) Llinas, P., Stura, E.A., Menez, A., Kiss, Z., Stigbrand, T., Millan, J.L., Le Du, M.H.J. Mol. Biol. 2005, 350, 441.

(13) de Backer, M. M., McSweeney, S., Lindley, P.F., Hough, E. Acta. Crystallogr., Sect. D 2004, 60, 1555.

(14) Agarwal, V., Borisova, S.A., Metcalf, W.W., van der Donk, W.A., Nair, S.K. Chem. Biol. 2011, 18, 1230.

(15) Holden, H. M., Benning, M.M., Dunaway-Mariano, D., Kim, A.D.

(16) Panosian, T. D., Nannemann, D.P., Watkins, G.R., Phelan, V.V., McDonald, W.H., Wadzinski, B.E., Bachmann, B.O., Iverson, T.M. J. Biol. Chem. 2011, 286, 8043.

(17) Fedorov, A. A., Bonanno, J., Fedorov, E.V., Burley, S.K., Almo, S.C.

(18) Tsuruta, H., Mikami, B., Higashi, T., Aizono, Y. Biosci. Biotechnol. Biochem 2010, 74, 69.

(19) Wende, A., Johansson, P., Vollrath, R., Dyall-Smith, M., Oesterhelt, D., Grininger, M. J. Mol. Biol. 2010, 400, 52. 
(20) Arai, S., Yonezawa, Y., Ishibashi, M., Matsumoto, F., Adachi, M., Tamada, T., Tokunaga, H., Blaber, M., Tokunaga, M., Kuroki, R. Acta. Crystallogr., Sect. D. 2014, $70,811$.

(21) Nowicki, M. W., Kuaprasert, B., McNae, I.W., Morgan, H.P., Harding, M.M., Michels, P.A., Fothergill-Gilmore, L.A., Walkinshaw, M.D. J. Mol. Biol. 2009, 394, 535.

(22) Mercaldi, G. F., Pereira, H.M., Cordeiro, A.T., Michels, P.A., Thiemann, O.H. Febs. J. 2012, 279, 2012.

(23) Rigden, D. J., Mello, L.V., Lamani, E., Littlejohn, J.E., Jedrzejas, M.J. J. Mol. Biol. 2003, 328, 909.

(24) Nukui, M., Mello, L.V., Littlejohn, J.E., Setlow, B., Setlow, P., Kim, K., Leighton, T., Jedrzejas, M.J. Biophys. J. 2007, 92, 977.

(25) Roychowdhury, A., Kundu, A., Bose, M., Gujar, A., Mukherjee, S., Das, A.K. Febs. J. 2015, 282, 1097.

(26) Lokanath, N. K., Pampa, K.J., Kunishima, N.

(27) Wang, E., Koutsioulis, D., Leiros, H.K., Andersen, O.A., Bouriotis, V., Hough, E., Heikinheimo, P. J. Mol. Biol. 2007, 366, 1318. 